Bangl. J. Vet. Med. (2010). 8(2) : $157-162$

\title{
PREVALENCE AND RISK FACTORS OF MASTITIS IN LACTATING DAIRY COWS AT BAGHABARI MILK SHED AREA OF SIRAJGANJ
}

\author{
M. A. Islam ${ }^{1 *}$, A.K.M. A. Rahman ${ }^{1}$, S. A Rony ${ }^{2}$ and M. S. Islam ${ }^{3}$ \\ ${ }^{1}$ Department of Medicine, ${ }^{2}$ Department of Parasitology, ${ }^{3}$ Department of Microbiology and Hygiene, Faculty of \\ Veterinary Science, Bangladesh Agricultural University, Mymensingh-2202, Bangladesh
}

\begin{abstract}
A cross-sectional study was carried out on a total of 330 lactating dairy cows at Baghabari, Sirajganj to determine the prevalence and risk factors of clinical (CM) and sub-clinical (SCM) mastitis using California Mastitis Test (CMT), White Side Test (WST) and Surf Field Mastitis Test (SFMT) during the period from July to December, 2009. Of all cows tested, 2.12\% $(\mathrm{n}=7)$ cows were affected with $\mathrm{CM}$ and $37.58 \%(\mathrm{n}=124), 36.67 \%(\mathrm{n}=121)$ and $35.15 \%(\mathrm{n}=116)$ cows showed positive reaction for SCM by CMT, WST and SFMT respectively. The overall prevalence of SCM was $36.46 \%$ and CMT showed better performance in detecting SCM $(37.58 \%)$ among three indirect tests used. The prevalence of SCM was significantly $(p<0.01)$ higher $(47.61 \%)$ in age group more than 13 years than others. A significantly $(\mathrm{p}<0.01)$ higher prevalence of SCM was observed in parity number more than 11 than others. The prevalence of SCM was significantly $(\mathrm{p}<0.01)$ higher $(37.12 \%)$ in cows yielding $>10 \mathrm{~L}$ of milk than others. The prevalence of SCM was highest in late lactation (72.45\%) followed by early $(40 \%)$ and mid lactation $(27.56 \%)$. Herds having 16 or more milch cows had significantly $(\mathrm{p}<0.05)$ higher SCM than those with fewer milch cows.
\end{abstract}

Keywords: Bovine Mastitis, prevalence, risk factors, Sirajganj

\section{INTRODUCTION}

Bovine mastitis is a single most common disease syndrome of adult dairy cows recognized mainly as clinical and sub-clinical types worldwide, which has great economic impact on dairy industry with complex multifactorial etiology (Nooruddin et al., 1997). It is estimated that one third of all dairy cows are infected with some form of mastitis in one or more quarters. The Clinical Mastitis (CM) is accompanied by physical, chemical, pathological and bacteriological changes in milk and glandular tissue (Samad, 2008). The Sub clinical mastitis (SCM) can be known only after laboratory examination, as there are no gross inflammatory changes in the udder tissue. In almost all cows microorganisms are mainly involved in mastitis but some factors, pendulous udder with long teats, larger size of teat orifice in high yielding cows, traumatic injuries etc. may play an important role as inciting factor of mastitis. Predisposing factors such as poor management and hygiene, teat injuries and faulty milking machines are known to hasten the entry of infectious agents and the course of the disease (Majic et al., 1993). In terms of economic loss mastitis is undoubtedly the most important disease with which the dairy industry has to contend. Once a cow suffers from mastitis it will never return to its normal milk production. Kader et al., 2003 reported that the annual economic loss due to reduced milk production alone caused by SCM in Bangladesh is Tk. 122.6 million (US \$ 2.11 million). Besides causing huge losses to milk production, the subclinically affected animals remain a continuous source of infection to other herd mates. The persistence of SCM in dairy cows may develop clinical mastitis at any time under certain stress factor (s). Early diagnosis of mastitis is essential because changes in the udder tissue take place much earlier than they become apparent.

The CM can easily be detected by inspection of udder and or systemic signs of inflammation, whereas, diagnosis of subclinical mastitis is more problematic since the milk appears normal but usually has an elevated somatic cell count. Various methods, based on physical and chemical changes of milk and cultural isolation of organisms, are used for diagnosis of subclinical mastitis (Emanuelson et al., 1987). Although bacteriological culture of milk samples is the gold standard method for identifying mastitis but it does not provide a measure of the degree of inflammation associated with the infection. Therefore, indirect tests viz. California Mastitis Test (CMT), White Side Test (WST), Surf Field Mastitis Test (SFMT) etc. can be used which are simple and do not require any complex laboratory equipment. Reagent of these tests is solutions containing detergents. Detergents decrease surface tension, change the structure and conductivity of cell membrane and nucleus, disturb osmotic balance, block oxidizing and stimulate proteolytic enzymes, and increase milk viscosity (Middleton et al., 2004).

*Corresponding author: e-mail: aminbau14@gmail.com 


\section{A. Islam and others}

Baghabari area of Sirajganj district was a traditional milk producing area. Bangladesh Milk Producers Cooperative Union Limited (BMPCUL), popularly known as Milk Vita: the brand name of its product, which organized farmers in the Baghabari area into cooperatives and started collecting milk in the area. Milk collected from several farmers mixed before reaching the consumer. Pathogens from mastitic milk have the chance to enter into healthy milk causing human health hazards. Information on prevalence of bovine mastitis and their associated risk factors in this area is scarce (Samad, 2000), even though this is one of biggest milk pocket of Bangladesh. Therefore, the present study was designed to determine the prevalence and risk factors associated with mastitis in lactating dairy cows in Bhagabari milk shed area of Sirajganj, Bangladesh.

\section{MATERIALS AND METHODS}

A cross-sectional study was carried out on a total of 330 lactating cows at Baghabari, Sirajgonj to determine the prevalence and risk factors of clinical and sub-clinical mastitis using California Mastitis Test (CMT), White Side Test (WST) and Surf Field Mastitis Test (SFMT) during July to December, 2009. The geographic location of study area is in between $24^{\circ} 20^{\prime} \mathrm{N} 89^{\circ} 37^{\prime} \mathrm{E} 24.33^{\circ} \mathrm{N} 89.62^{\circ} \mathrm{E}$. The annual average temperature of this area reaches a maximum of $34.6{ }^{\circ} \mathrm{C}$, and a minimum of $11.9^{\circ} \mathrm{C}$ and average annual rainfall is $1610 \mathrm{~mm}(63.4 \mathrm{in})$.

\section{Study population and husbandry practices}

Study animals include cross-bred dairy cows of Jersey, Holstein-Fresian and Shahiwal breed. Both intesnsive (when bathan i.e. pasture land, goes under water) and extensive (in bathan) system of animal management prevails in this area. In addition to forage consumed from bathan some concentrates are also provided to the animals. This type of dairy husbandry system enhances cost-effective milk production and thereby income generation of the small-holder dairy farmers in Baghabari zone.

\section{Survey design and sampling}

A cross-sectional observational study was undertaken using random sampling technique. Twenty four herds of variable sizes (7-180) were randomly selected. Almost all lactating cows of the selected herds were included to take milk samples. Sample size (330) was determined following the procedure described by Putt et al. (1987) assuming an expected prevalence of $20 \%$ and precision of $95 \%$.

\section{Clinical inspection of udder}

The udder was first examined visually and then through palpation to detect possible fibrosis, inflammatory swellings, visible injury, atrophy of the tissue, and swelling of supra mammary lymph nodes. The size and consistency of mammary quarters were inspected for the presence of any abnormalities, such as disproportional symmetry, swelling, firmness, and blindness. Viscosity and appearance of milk secretion from each mammary quarter were examined for the presence of clots, flakes, blood, and watery secretions. Injuries caused by vigorous calf suckling were identified as circumscribed lesions around the teats.

\section{Detection of mastitis}

Clinical mastitis was detected based on results of clinical inspection of udder and signs of systemic involvement. Sub-clinical mastitis was diagnosed based on results of indirect tests and the nature of coagulation and viscosity of the mixture, which show the presence and severity of the infection, respectively. The following indirect tests were used for detection of subclinical mastitis in dairy cows:

\section{a. White Side Test (WST)}

The WST was performed as per procedure described by Kahir (2006). In brief, $50 \mu 1$ (five drops) of milk were placed on a glass slide with a dark background by micropipette. And then $20 \mu 1$ of WST reagent $(4 \% \mathrm{NaOH})$ were added to the milk sample and the mixture was stirred rapidly with a toothpick for $20-25$ seconds. A breaking up of milk in flakes, shreds and viscid mass was indicative of positive reaction. On the other hand, milky and opaque and entirely free of precipitant was indicative of negative reaction. The grading of positive WST scores was shown in Table 1.

\section{b. Surf Field Mastitis Test (SFMT)}

This test was performed and scored following the method described by (Muhammad et. al., 1995). In brief, 2

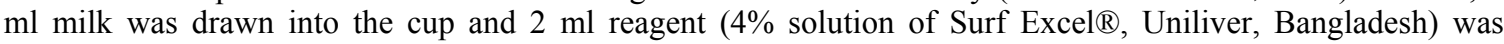
squirted from a polyethylene wash bottle. Mixing was accomplished by gentle circular motion of the paddle in a horizontal plane for few seconds. The reaction developed almost immediately with milk containing a high concentration of somatic cells. The peak of reaction was obtained within 30 seconds and immediately scored as $1+, 2+$ and $3+$ like WST. 
Table 1. Grading of the White Side Test (WST) scores

\begin{tabular}{llc}
\hline \multicolumn{1}{c}{ Visible reaction } & Interpretation & Symbol \\
\hline Mixture is milky and opaque and entirely free of precipitant & Negative & - \\
The background is less opaque but still somewhat milky, with larger & Weak positive & $1+$ \\
particles of coagulated materials being present and thickly scattered & \\
through the area. A slight degree of clumping is observed & \\
$\begin{array}{l}\text { The background is more watery and large clumps of coagulated materials } \\
\text { are present. If the stirring has been rapid, fine threads or strings may be }\end{array}$ & \\
$\begin{array}{l}\text { present. } \\
\begin{array}{l}\text { The background is very watery and whey-like, with large masses of } \\
\text { coagulated material forming into strings and shreds. }\end{array}\end{array}$ & $2+$ \\
\hline
\end{tabular}

\section{c. California Mastitis Test (CMT)}

The CMT kit (Leucocytest ${ }^{\circledR}$, Synbiotic Corporation, France) was used for screening of milk samples for subclinical mastitis. The procedure of CMT was performed as per manufacturer's instruction, in brief; $2 \mathrm{ml}$ milk was drawn into the cup and an estimated equal volume of CMT reagent was squirted from a polyethylene wash bottle. Mixing was accomplished by gentle circular motion of the paddle in a horizontal plane for few seconds. The reaction developed almost immediately with milk containing a high concentration of somatic cells. The peak of reaction was obtained within 10 seconds and scored. The CMT results were read immediately as per manufacturer's recommendation and were scored based on the amount and thickness of gel formed as described by Ikram (1997) as shown in Table 2.

Table 2. Scoring of California mastitis test results

\begin{tabular}{|c|c|c|c|c|}
\hline \multicolumn{3}{|l|}{ Reading } & \multicolumn{2}{|c|}{ Interpretation } \\
\hline \multirow[t]{2}{*}{ Aspect } & \multicolumn{2}{|c|}{ Score } & \multirow[t]{2}{*}{ Infection } & \multirow{2}{*}{$\begin{array}{l}\text { Related with the average } \\
\text { cellular } \\
\text { NUMERATIO N } \\
\left(\times 10^{3} / \mathrm{ml}\right)\end{array}$} \\
\hline & Value & Cross & & \\
\hline Consistency normal or gray color. & 0 & $(0)$ & Absent & 100 \\
\hline $\begin{array}{l}\text { Light gel disappearing after stirring or } \\
\text { Purplish gray color }\end{array}$ & 1 & $( \pm)$ & $\begin{array}{l}\text { Infection risk by minor } \\
\text { pathogenic }\end{array}$ & 300 \\
\hline $\begin{array}{l}\text { Light persistent gel-crumbly filaments } \\
\text { or Purple gray }\end{array}$ & 2 & $(+)$ & Sub-clinical mastitis & 900 \\
\hline $\begin{array}{l}\text { Immediate thickening viscous cluster } \\
\text { at the bottom of the well. }\end{array}$ & 3 & $(++)$ & Sub- clinical mastitis & 2700 \\
\hline $\begin{array}{l}\text { Thick gel, egg white consistency with } \\
\text { dark purple color. }\end{array}$ & 4 & $(-)$ & $\begin{array}{l}\text { Sub-clinical mastitis } \\
\text { near the clinical } \\
\text { expression }\end{array}$ & 8100 \\
\hline
\end{tabular}

\section{Data collection}

A pre-tested questionnaire was used to collect both herd and animal level data including type of dairy husbandry system, breed, age, parity, lactation stage, milk yield and herd size. Udder and milk abnormalities (injuries, blindness, tick infestation and indurations, swelling, milk clots, abnormal secretion, etc.) were recorded. Depending on the clinical inspection findings, cases were categorized as clinical mastitis positive or negative. Age of the animals was determined by asking the owner and dentition characteristics and categorized as young adults ( $>3$ to 6 years), adults ( $>6$ to 10 years), and old $(>10)$. Stage of lactation was categorized as early $\left(1^{\text {st }}\right.$ to $4^{\text {th }}$ month), mid ( $4^{\text {th }}$ to $8^{\text {th }}$ month $)$, and late $\left(8^{\text {th }}\right.$ month to the beginning of dry period). Parity was categorized as few (with 2-3 calves), moderate (with 4-7 calves) and many ( $>7$ calves). 


\section{A. Islam and others}

\section{Statistical analysis}

Data was entered in Microsoft excels 2003 and transferred to $\mathrm{R}^{\circledR}$, Version 2.10.0 (The R Foundation for Statistical Computing, Vienna, Austria) for further analysis. Descriptive statistics were obtained from Rattle (A Data Mining GUI for R). Risk factors were identified using multiple logistic regression models using a backward stepwise procedure (Hosmer and Lemeshow 1989). A significance level was selected as 5\%.

\section{RESULTS AND DISCUSSION}

Mastitis of any form reduced milk production, besides that milk quality can also be affected by clinical or subclinical bovine mastitis which also serves as sources of a number of milk borne infections like tuberculosis, brucellosis in humans. Therefore, an attempt was made to determine the prevalence and risk factors of bovine mastitis of dairy cows of Baghabari milk shed area, Sirajganj.

\section{Overall prevalence of SCM}

The udder of all selected cows $(n=330)$ used for milk sampling were examined thoroughly and it was found that $2.12 \%(\mathrm{n}=7)$ cows were affected with clinical form of mastitis. All the milk samples of 330 lactating cows were screened for SCM of which $37.58 \%(n=124), 36.67 \%(n=121)$ and $35.15 \%(n=116)$ cows showed positive reaction detected by CMT, WST and SFMT respectively (Table 3). The overall prevalence of subclinical mastitis showed $36.46 \%$ and CMT showed better performance in detecting sub-clinical mastitis (37.58\%) among three indirect tests used. These results are comparable to Kader et al. (2002) who reported 46.6\% SCM in cross-bred lactating cows on bacteriological examination of milk samples in Bangladesh. Also higher prevalence rates reported by Motice et al. (1985) and lower prevalence rates reported by Nooruddin et al. (1997) and Rahman et al. (1997). These differences of prevalence rates of SCM might be due to difference of breed, management systems and test used for screening of milk samples.

Table 3. Prevalence of SCM in cross-bred cows detected by three different indirect tests

\begin{tabular}{llccccc}
\hline S/N & Tests used & No of cows & \multicolumn{4}{c}{ Positive results } \\
\cline { 4 - 7 } & & tested & $\mathbf{1 +}$ & $\mathbf{2 +}$ & $\mathbf{3 +}$ & Total \\
\hline 1 & White side test (WST) & 330 & 63 & 41 & 17 & $121(36.67 \%)$ \\
2 & Surf Field Mastitis Test (SFMR) & 330 & 61 & 38 & 16 & $116(35.15 \%)$ \\
3 & California Mastitis Test (CMT) & 330 & 64 & 41 & 19 & $124(37.58 \%)$ \\
& & & & Overall Prevalence & $\mathbf{3 6 . 4 6 \%}$ \\
\hline
\end{tabular}

\section{Age wise prevalence of SCM}

The distribution of SCM in different age group is presented in Table 4. The prevalence of SCM was significantly $(p<0.01)$ higher $(47.61 \%)$ in the age group belonging to more than 13 years than others. The prevalence of clinical mastitis was also increased in older cows. Similar observation was also reported by Rahman et al. (2009).

\section{Breed wise prevalence of mastitis}

The breed wise distribution of SCM in dairy cows is presented in Table 4. No significant difference was observed in different breeds of cow. Similar findings also recorded by Rahman et al. (2009).

\section{Prevalence of mastitis in relation to number of parity}

The distribution of SCM in different parity group of lactating cows is shown in Table 4. Significantly $(\mathrm{p}<0.01)$ higher prevalence $(50 \%)$ of SCM was recorded at the parity group of more than 11 . Similarly prevalence of clinical mastitis was also increased with increased number of parity of cows. This observation supports the reports of Rasool et al. (1985); Devi et al. (1997) and Dego and Tareke (2003).

\section{Prevalence of mastitis in relation to milk yield}

The distribution of SCM in relation to milk yield is presented in Table 4. The prevalence of SCM was significantly $(\mathrm{p}<0.05)$ higher $(37.12 \%)$ in high $(>10 \mathrm{~L})$ yielding cows than low to medium yielders. This finding was in agreement with the reports of Kader et al. (2003). 
Prevalence and risk factors of bovine mastitis

\section{Prevalence of mastitis at different stage of lactation}

The distribution of clinical and sub clinical mastitis in dairy cows in different stage of lactation is presented in Table 4. The prevalence of SCM was highest in late lactation $(72.45 \%)$ followed by early $(40 \%)$ and mid lactation (27.56\%) which is comparable to the findings of Rabbani and Samad (2010). However these results contradict with Pal and Verma (1988a) who reported lower prevalence of SCM in the stage of lactation above five months. Review of literature revealed that the highest incidence of CM usually occurred during early stage of lactation as high milk production enlarged status of udder which particularly prone to infection and inflammatory process and also for physiological stress caused by heavy milk yield, but the prevalence of SCM could be high at late stage of lactation due to long exposure time.

Table 4. Distribution of clinical and subclinical Bovine mastitis in Crossbred cows of Baghabari milk shed area detected by clinical examination and indirect tests (Dairy cows are considered positive for SCM if at one test showed positive reaction).

\begin{tabular}{|c|c|c|c|c|c|}
\hline Variables & Category levels & $\begin{array}{l}\text { No of } \\
\text { cows }\end{array}$ & $\begin{array}{l}\text { Clinical } \\
\text { mastitis } \\
\text { No. (\%) }\end{array}$ & $\begin{array}{c}\text { Subclinical } \\
\text { Mastitis } \\
\text { No. (\%) } \\
\end{array}$ & $\begin{array}{c}\text { Not infected with } \\
\text { mastitis } \\
\text { No. (\%) } \\
\end{array}$ \\
\hline \multirow[t]{6}{*}{ Age } & Less than 5 years & 19 & $0(0.00 \%)$ & $7(36.84 \%)$ & $12(63.15 \%)$ \\
\hline & From 5 to $<7$ years & 109 & $0(0.00 \%)$ & $46(42.22 \%)$ & $63(57.78 \%)$ \\
\hline & From 7 to $<10$ years & 122 & $4(3.28 \%)$ & $52(42.62 \%)$ & $70(57.37 \%)$ \\
\hline & Bet 10 to 13 years & 59 & $3(5.08 \%)$ & $27(45.76 \%)$ & $29(49.15 \%)$ \\
\hline & More than 13 years & 21 & $0(0.00 \%)$ & $10(47.61 \%) * *$ & $11(52.38 \%)$ \\
\hline & Sub total & 330 & $7(2.12 \%)$ & $116(35.15 \%)$ & $207(62.73 \%)$ \\
\hline \multirow[t]{4}{*}{ Breed } & Fresian cross & 261 & $6(2.29 \%)$ & $96(36.78 \%)$ & $159(60.92 \%)$ \\
\hline & Jexsey cross & 27 & $1(3.70 \%)$ & $5(18.52 \%)$ & $21(77.78 \%)$ \\
\hline & Shahiwal cross & 42 & $0(0.00 \%)$ & $15(35.71 \%)$ & $27(64.29 \%)$ \\
\hline & Sub total & 330 & $7(2.12 \%)$ & $116(35.15 \%)$ & $207(62.73 \%)$ \\
\hline \multirow[t]{5}{*}{ Parity No } & $1-3$ & 164 & $0(0.00 \%)$ & $55(33.54 \%)$ & $109(66.46 \%)$ \\
\hline & $4-7$ & 121 & $5(4.13 \%)$ & $43(35.56 \%)$ & $73(60.33 \%)$ \\
\hline & $8-11$ & 38 & $2(5.26 \%)$ & $15(39.47 \%)$ & $21(55.26 \%)$ \\
\hline & $>11$ & 6 & $0(0.00 \%)$ & $3(50 \%) * *$ & $3(50.0 \%)$ \\
\hline & Sub total & 330 & $7(2.12 \%)$ & $116(35.15 \%)$ & $207(62.73 \%)$ \\
\hline \multirow[t]{4}{*}{ Milk Yield } & $\operatorname{Low}(1-5 \mathrm{~L})$ & 24 & $0(0.00 \%)$ & $7(29.92 \%)$ & $17(70.08 \%)$ \\
\hline & Medium (6-10L) & 115 & $1(0.87 \%)$ & $38(33.04 \%)$ & $76(66.08 \%)$ \\
\hline & $\operatorname{High}(>10 \mathrm{~L})$ & 191 & $6(3.14 \%)$ & $71(37.12 \%) * *$ & $114(59.69 \%)$ \\
\hline & Sub total & 330 & $7(2.12 \%)$ & $116(35.15 \%)$ & $207(62.73 \%)$ \\
\hline Lactation & Early (<3 months) & 25 & $0(0.00 \%)$ & $10(40 \%)^{*}$ & $15(60 \%)$ \\
\hline \multirow[t]{3}{*}{ Stage } & Mid (3-6months) & 127 & $4(3.15 \%)$ & $35(27.56 \%)$ & $86(67.72 \%)$ \\
\hline & Late ( $>6$ months) & 98 & $3(3.06 \%)$ & $71(72.45 \%)^{*}$ & $24(24.49 \%)$ \\
\hline & Sub total & 330 & $7(2.12 \%)$ & $116(35.15 \%)$ & $207(62.73 \%)$ \\
\hline No. of milch & Small (1-5) & $6^{\mathrm{a}}$ & $0(0.00 \%)$ & $1(16.66 \%)$ & $5(83.33 \%)$ \\
\hline \multirow[t]{3}{*}{ cow per herd } & Medium(6-15) & $8^{\mathrm{a}}$ & $1(12.50 \%)$ & $5(62.50 \%)$ & $2(25.0 \%)$ \\
\hline & Large $(16$ to $\geq 60)$ & $10^{\mathrm{a}}$ & $2(20.0 \%)^{*}$ & $7(70.0 \%)^{*}$ & $1(10.00 \%)$ \\
\hline & Sub total & 24 & $3(12.50 \%)$ & $13(54.17 \%)$ & $8(33.33 \%)$ \\
\hline
\end{tabular}

*Significant level $(\mathrm{p}<0.05)$; ** Significant level $(\mathrm{p}<.01){ }^{\mathrm{a}}=$ No. of herd studied

\section{Prevalence of SCM in relation to number of milch cows per herd}

Among 24 farms of different sizes examined for mastitis, $12.50 \%(n=3)$ were affected with clinical mastitis and $54.17 \%(n=13)$ were affected with SCM. It was observed that the prevalence of SCM was significantly $(p<0.05)$ higher with the increased number of milch cows per herd. Herds having 16 to $\geq 60$ milch cows per herd had significantly higher $(70.0 \%)$ prevalence of SCM than those with fewer milch cows. This observation supports the report of Rahman et al. (2009).

This study reveals that the stages of lactation, number of parity, level of milk yield and number of milch cows per herd are the important factors associated with the prevalence of SCM in cows. Further investigation to identify the pathogens and anti-biogram of isolates should be done for effective control of SCM in dairy cows. 


\section{A. Islam and others}

\section{REFERENCES}

1. Dego OK and Tareke F (2003). Bovine mastitis in selected areas of Southern Ethiopia. Tropical Animal Health and Production 35: 197-205.

2. Devi BK, Shukla PC and Bagherwal RK (1997). Incidence of sub-clinical mastitis in cows. Indian Journal Dairy Science 50: 477-478.

3. Emanuelson U, Olsson T, Holmberg O, Hageltorn M, Mattila T, Nelson L and Astrom G (1987). Comparison of some screening tests for detecting mastitis. Journal of Dairy Science 70: 880-886.

4. Hosmer DW and Lemeshow S (1989) Applied Logistic Regression. New York: Wiley, xiii: 307.

5. Ikram M (1997). Diagnostic microbiology. In: Paul W and Pratt VMD (editors), Laboratory Procedures for Veterinary Technicians. R R Donnelley and Sons Company. St. Louis, Missouri. Pp.159-160

6. Kader MA, Samad MA, Saha S and Taleb MA (2002). Prevalence and aetiology of sub-clinical mastitis with antibiotic sensitivity to isolated organisms among milch cows in Bangladesh. Indian Journal of Dairy Science 55:218-223.

7. Kader MA, Samad MA and Saha S (2003). Influence of host level factors on prevalence and economics of subclinical mastitis in dairy cows in Bangladesh. Indian Journal of Dairy Science 56:235-240.

8. Kahir MA (2006). A Cross sectional epidemiological study on subclinical mastitis of dairy cows in Sylhet. MS thesis, Department of Medicine, Bangladesh Agricultural University, Mymensingh.

9. Majic B, Jovanovic BV, Ljubic Z and Kukovics S (1993). Typical problems encountered in Croatia in the operation of goats milking machines. Proceedings of the $5^{\text {th }}$ Internacional symposium on machine milking of small ruminants. Budapest, Hungary. pp. 377-379.

10. Middleton JR, Hardin D, Steevens B, Randle R and Tyler J (2004). Use of somatic cell counts and California mastitis test results from individual quarter milk samples to detect subclinical intramammary infection in dairy cattle from a herd with a high bulk tank somatic cell count. Journal of the American Veterinary Medical Association 224: 419-423.

11. Motice A, Ramudit S and Mohabir R (1985). Sub-clinical mastitis I dairy cattle in Guyana. Tropical Animal Health Product 17: 245-246.

12. Muhammad G, Athar M, Shakoor A, Khan MZ, Fazal-ur-Rehman and Ahmad MT (1995). Surf Field Mastitis Test: An inexpensive new tool for evaluations of wholesomeness of fresh milk. Pakistan Journal of Food Science 5:91-93.

13. Nooruddin M, Ali ML and Debnath NC (1997). Retrospective epidemiologic study of periparturient diseases in dairy cows. 1. Clinical mastitis. The Bangladesh Veterinarian 14: 43-47.

14. Pal P and Verma BB (1988a). Some observation on efficacy of indirect test for detection of sub-clinical mastitis. Indian Journal Veterinary Medicine 8: 40-41.

15. Putt SNH, Shaw APM, Woods AJ, Tyler L and James AD (1987). Veterinary epidemiology and economics in Africa. A manual for use in the design and appraisal of livestock health policy. ILCA Manual No. 3. 2nd Ed. International Livestock Centre for Africa: Addis Abeba, Ethiopia: 35.

16. Rabbani AFMG and Samad MA (2010). Host determinants based comparative prevalence of subclinical mastitis in lactating Holstein Frisian cross cows and red Chittagong cows in Bangladesh. Bangladesh Journal of Veterinary Medicine 8(1): 17-21.

17. Rahman MA, Bhuiyan MMU, Kamal MM and Shamsuddin M (2009). Prevalence and risk factors of mastitis in dairy cows.The Bangladesh Veterinarian 26(2): $54-60$

18. Rahman MS, Nooruddin M and Rahman MM (1997). Prevalence and distribution of mastitis in cross-bred and exotic dairy cows. Bangladesh Veterinary Journal 14: 1-4.

19. Rasool G, Jabbar MA, Kazmi SE and Ahmed A (1985). Incidence of sub-clinical mastitis in Nilli-Ravi buffaloes and Sahiwal cows. Pakistan Veterinary Journal 5: 76-78.

20. Samad MA (2008). Animal Husbanry and Veterinary Science, volume II, LEP pub no.11, Bangladesh Agricultural University campus, Mymensingh. Pp.1184-1189.

21. Samad MA (2000). An overview of livestock research reports published during the twentieth century in Bangladesh. Bangladesh Veterinary Journal 34: 53-149. 